\title{
CSR within SMEs: Literature Review
}

\author{
Amina Kechiche ${ }^{1}$ \& Richard Soparnot ${ }^{2}$ \\ ${ }^{1}$ Department of Law, Economics and Social Science, Institute of Business Administration, University of Tours, \\ Tours, France \\ ${ }^{2}$ Loire Valley University/CRESCEM/ESCEM, Groupe ESCEM, Tours, France
}

Correspondence: Richard Soparnot, Professor of Strategy and Management, Loire Valley University/CRESCEM/ESCEM, VALLOREM EA 6296, Groupe ESCEM, 1 Rue Léo Delibes, BP 0535, 37205 Tours Cedex 3, France. Tel: 33-2-477-7168. E-mail: rsoparnot@escem.fr

Received: November 1, 2012 Accepted: April 1, 2012 Online Published: July 1, 2012

doi: 10.5539/ibr.v5n7p97 URL: http://dx.doi.org/10.5539/ibr.v5n7p97

\begin{abstract}
Although CSR has traditionally been associated with big business, the SME business sector is such a significant sector worldwide in terms of the economic, environmental and social impact it makes, that attention has been turned to discussion and analysis of principles and practice of CSR in small and medium size businesses. SMEs are not merely small versions of big businesses, so as a result a particularly fast-growing body of academic work has become focused on commitment to CSR in the sector. As a result, the aim of this article is to set out an analysis of the main work carried out on the subject of CSR in SMEs. The analysis is a four part summary. In the first part, we explore the definition and the main CSR practices found in SMEs. The second part relates to determining characteristics of commitment to CSR within SMEs. Next we set out the challenges for SMEs and the constraints made upon them by CSR. Finally, the last section deals with positive examples of CSR in SMEs. Taking this literature review summary as a structural basis we then go on to demonstrate 3 research methodologies.
\end{abstract}

Keywords: CSR, SME

\section{Introduction}

Over the past fifteen years, discussion about CSR and its implementation in practice has increased in both variety and volume. In 1953 Bowen first introduced the idea of CSR- describing it as an obligation for companies to take certain factors into consideration during the course of their business activities and development of these factors has continued to this day. Those factors are as follows: - the obligation to take into account the impact of a company's activities upon its human, social and ecological environment, and in particular to see responsibility as stretching beyond responsibility to a company's shareholders. From that point on, CSR came to be considered as the introduction and implementation of sustainable development within the sphere of management.

The new awareness encouraged companies to implement practices compatible with the values of their business and to take into account the expectations of all its stakeholders- namely employees, suppliers, clients, consumers, the local community, environmental associations and NGOs - all those falling within Freeman's theoretical definition of a stakeholder as "any individual or group of individuals who can affect or is affected by the achievement of an organization's objectives”(Freeman, 1984: 46).

In the beginning, involvement was mostly restricted to larger companies. However, although CSR was traditionally seen as the province of big business, because the SME business sector is such a significant sector worldwide in terms of the economic, environmental and social impact it makes, attention has been turned to discussion and analysis of the principles and practices in small and medium size businesses with the result that this sector no longer finds itself outside the CSR movement (Spence, 1999; Spence et al., 2003, 2004; Jenkins, 2004, 2009; Murillo \& Lozano, 2009). Since SMEs are not just smaller versions of larger scale businesses (Jenkins, 2004) special attention needs to be paid to the specific ways in which they implement CSR measures, how these differ from practices in larger firms and how this explains different perceptions and behaviors in between the two in relation to sustainable development.

The aim of this article is to provide an overview of developments in relation to sustainable development as seen in the small and medium size business sector and to back this up by way of specific example. Our analysis of CSR within SMEs takes the form of a four part summary which enables us to discuss the wide range of intellectual 
contribution in thisburgeoning research area. In the first part of this article we define the term CSR and give examples of it in practice in SMEs. In the second part we concentrate on the determining characteristics of corporate commitment within SMEs. Next we look at the challenges and constraints involved in the implementation of CSR for SMEs and then finally we offer positive successful examples of CSR in SMEs.

\section{CSR within SMEs: Definition and Practices}

From the SME point of view, we thought it important to start by setting out how CSR is defined by researchers and managing directors, especially since the majority of the latter claim to subscribe to CSR (Saulquin \& Schier, 2007; Berger-Douce, 2008).

Taking the results of a "UK-wide study of socially responsible SMEs", Jenkins (2009) pointed out that for businesses considered to be exemplary in this area "CSR was seen as an 'all-embracing' idea that concerns having an awareness of the impact of the business, and wanting to have a positive impact on a wide range of stakeholders through the business decisions that are made”. Directors of SMEs in this survey don't see CSR as an external add-on but more as an integral part of the way they manage their firm.

In the same way, Blombäck and Wigren (2009) believe that commitment of a company to CSR relates to a firm's operational activities, such as the introduction of measures which respect the environment, and can embrace the social by involvement in the community and by maintaining good working relations with local actors (local sponsorship of events for e.g...).

Other research has chosen to focus on CSR measures implemented by SMEs and has attempted to classify the level and type of commitment involved. Three main categories are isolated (Vives, 2006; Russo \& Tencati, 2009): firstly internal social measures such as the development of talent, the implementation of health and social security measures and the improvement of working conditions... Secondly, external social measures such as the development of network links with the local economy, professional development and social integration... and finally, environmental measures such as the reduction of energy consumption, reduction of waste and waste recycling...

On this topic, the barometer of sustainable development within French SMEs (CROCIS, 2007) reports that the vast majority of heads of business claim to have implemented sustainable development measures, state that they manage their business with environment saving measures in mind (96\% in the Paris area) and indicates that some $47 \%$ of SMEs have good links with the community through sponsorship deals, charitable events, and back-to-work/employability schemes... (as opposed to 60 to 70\% of SMEs reported by Berger-Douce in 2008). The local community therefore would seem to be an important stakeholder for the majority of SMEs studied. The same picture emerges in relation to employees who appear to be well-treated within the majority of SMEs (Saulquin \& Schier, 2005; Berger-Douce, 2008; Hammann et al., 2009). Many examples of measures targeting talent development, improvements in working conditions or diversity in the workplace in terms of age and gender (Saulquin \& Schier, 2005; Berger-Douce, 2008) are recorded.

These results confirm the findings ofSaulquin and Schier (2010) who examine CSR in SMEs from the point of view of different stakeholders. They report that great sensitivity is shown by SMEs in relation to the wellbeing of their employees and their community links. This is explained by the closeness of relationships between managing directors and their staff and by the fact that SMEs often have very strong links with their immediate locality (Torrès, 2003).

The wide variety of CSR practices and measures in SMEs covered in research work has paved the way for further research to be carried out into specific factors which can assist the integration and implementation of CSR measures by SME directors. We will examine some of these main factors in the following section.

\section{Determining Characteristics of Corporate Commitment within SMEs}

SMEs can vary greatly in terms of size, mission, sector... and so commitment to CSR depends on various factors. Lepoutre and Heene (2006) identify characteristics such as the individual personality of business directors, organizational factors and other characteristics depending on context which all explain the differences in uptake and style of CSR in practice. Similarly, Labelle and Saint Pierre (2010) identify three groups of factors (institutional, organizational and personnel) which can influence the decision to implement responsible policy. Nonetheless, certain factors and characteristics such as the size of the business, localization as well as individual factors (linked to the personality of the business head of the SME) are more commonly identified in the research than others.

The size of a business is an organizational factor in the uptake and implementation of CSR by SMEs (Labelle \& Saint Pierre, 2010). Some studies suggest the existence of a positive link between the size of a firm and its 
commitment to CSR (Lepoutre \& Heene, 2006; Perrini et al., 2007; Cabagnols \& Le Bas, 2008). Larger sized SMEs are more sensitive to CSR issues than smaller or micro businesses particularly on the environmental front (Sharma, 2000). Larger businesses are often more able to absorb fixed costs as well as having greater access to resources. A larger workforce might make certain factors more likely (Berger-Douce, 2008). However, the picture on the ground is very subtle and research findings vary on this issue.

Another determining factor is the critical role played by the business head of an SME. The smaller scale of the business increases the personal contact a director can have with his staff and creates more informal working relations as well as a smaller gap between the strategic and operational centers of the business (Torrès, 2000). The same dynamic exists externally between the company and outside actors (Julien \& Marchesnay, 1996; Torrès, 1999). This could mean that SME directors are more likely to develop ways of thinking about CSR which are more ethical than economic in nature.

According to a survey conducted by CROCIS-Médiamétrie (2008), the main driver behind the implementation of CSR policies according to $64.7 \%$ of SME directors interviewed, is citizenship. Personal or individual reasons therefore remains the most important of all motivational factors in French SMEs thus confirming the findings of Courrent (2004), Hemingway (2005) and Murillo and Lozano (2006).

According to several academics (Paradas, 2006; Spence et al., 2007a; Spence et al., 2007b) this public spiritedness or citizenship is a reflection of the personal values and convictions of a company's manager. In fact, according to Gond and Igalens (2008) "CSR in a SME depends very much upon the personality and personalconvictions of its managing directors”. Similarly, Spence et al. (2007a) highlight the fact that it is a director's vision for the future of his business and his understanding and perception of internal resources which influences commitment to CSR. Directors of SMEs are not subject to pressure from shareholders keen to see short term returns and this frees them up to invest in the field of human dynamics and the forging of relations with all stakeholders, mindful of the fact that profit-making is not the only raison d'être for a company.

Following on from this, research academics have explored and tried to explain the determining components of a director's ethical value system. Ede et al. (2000) suggest that age plays a significant part in the value system of an SME director concluding that younger directors are more socially responsible than their elders. Similarly, they believe that neither gender nor education has any significant role to play when it comes to a director's value acquisition. However, other academics suggest that the educational level of a company director does play a significant role in this domain (Spence \& Lozano, 2000).

Other authors believe that territorial cohesion and company's local foothold might have an effect upon the implementation of CSR initiatives. The majority of SMEs have strong local attachments and identify generally with the region where they are based. In addition, the local area offers businesses the benefit of many resources such as infrastructure, workforce, raw materials, and expects in exchange some economic and community benefit by way of reciprocation. A director therefore has to make sure his practices fit in with the values and expectations of the local community.

According to Torrès (2003:125) "from an external point of view, the image of a company will be affected by the human relationship capital a director can bring to the job and this often plays a key role in his public, professional, social and political dealings". These relations which connect the SME to different external actors are particularly important for the encouragement and implementation of CSR measures and practices and can even influence the behavior of other SMEs in the same sector. In this regard, the aim is to deal collectively with ecological and social issues, to reduce the cost of implementation and to go beyond the constraints imposed by some types of market.

Following this reasoning through further, some authors believe that commitment to CSR in SMEs is all down to the pressure applied by stakeholders (Worthington et al., 2008). Lepoutre and Heene (2006) believe that SMEs are more sensitive to practices relating to internal stakeholders e.g. their employees, clients and suppliers. In fact, according to several authors, these are the three most influential stakeholders for SMEs (Murillo \& Lozano, 2006; Perrini et al., 2007; Saulquin \& Schier, 2005, Gadenne et al., 2009). This hypothesis carries even more weight when we consider that many SMEs work together with big businesses and are therefore encouraged to develop and change their methods of production, at the same time as preserving the environment and guaranteeing equitable social dealings. Lapointe (2006) is of the opinion that it is through the intermediary of the value chain - mainly the pressure exerted by big business, that SMEs commit to and implement CSR practices.

Continuing this debate further, other research studies conclude that in the case of SMEs, pressure exerted by stakeholders is often not very effective and is not the catalyst for a business to implement measures which go beyond legal and administrative requirements (Worthington et al., 2006; Ellerup Nielsen \& Thomsen, 2009). According to Courrent (2006), SMEs are not very keen on collective issues. For their part, in relation to the 
implementation by SMEs of CSR policies, Quairel and Auberger (2007) believe that France is not particularly influenced by big business in this regard.

The aim of this section was to highlight the main determining components behind implementation of CSR in SMEs. Next we are going to give an overview of the constraints and challenges associated with the implementation of CSR for SMEs. This is the third area of academic research studies into CSR in SMEs.

\section{A Complex Commitment for a SME}

Although SMEs are integrating CSR more and more into their day-to-day management, they have to overcome many obstacles in order to do so. Several research studies have explored the constraints to successful implementation of sustainable development for SMEs in a wide range of business contexts (Observatoire des PME, 2003; Lapointe \& Gendron, 2004; Berger-Douce, 2007; Crocis-CCIP, 2007).

Whilst acknowledging an increase in levels of awareness of CSR, the above studies indicate that some directors remain skeptical as to the benefits to be derived from CSR initiatives and are not inclined to go beyond what is strictly required of them legally (Revell \& Blackburn, 2007). In actual fact, these directors report that they are pretty much overwhelmed by the day-to-day operation of their business, and too busy to concern themselves much with issues relating to society at large which have no immediate return or benefit (Lepoutre \& Heene, 2006). They also report that there is a lack of information about CSR and that this hasn't exactly encouraged them to become committed. On this specific point, the barometer of sustainable development - the Crocis-CCIP survey also highlights the fact that lack of information is the first obstacle to implementation of responsible management on the part of SME directors (47\% in 2007) despite numerous initiatives and campaigns to increase awareness and help directors overcome this very same obstacle (AFCI, 2006).

Moreover, SMEs don't generally have the capacity to collect and analyze useful data on the subject of sustainable development themselves (Lepoutre \& Heene, 2006). In addition, their access to information is limited as too is their knowledge of CSR- whether this is gathered from technical support organizations orreference data. A study of some 138 SMEs conducted by Berger-Douce (2008) illustrated that less than 30\% of SMEs knew anything about support organizations which offer assistance for CSR start up initiatives and less than $25 \%$ knew anything about CSR reference data. This lacuna illustrates a reactive as opposed to a pro-active approach in relation to the issue of seeking out information.

A further barrier is the cost of implementing reasonable measures and the lack of financial resources to do so (ACFCI, 2006; Lepoutre \& Heene, 2006; Roberts et al., 2006; Berger-Douce, 2008; Revell \& Blackburn, 2007). The perception of a company's resources as seen from the point of view of its managing director is a crucial matter here (Spence L. et al., 2007). SME directors who believe that their companies do not have sufficient financial resources are less likely to think favorably about CSR and to believe that the resources required for investment will not be compensated for in terms of cost savings.

Commitment of SMEs also meets obstacles linked to the market, principally the difficulty of applying environmental and/or social legislation because of its complexity and the rigidity involved in certain procedures. SMEs also lament the lack of adequate support services and infrastructure.

A lack of availability of tools is also blamed for lack of uptake. Those which exist appear to be designed for big business and not easily adaptable to SMEs (Studer et al., 2006). Formal systems of environmental management have thus not been very successful amongst SMEs because their complexity precludes adoption by smaller structures (Watson \& Emery, 2004 quoted by Berger-Douce, 2010).

Despite the barriers SMEs face, the idea of implementing CSR measures nonetheless continues to take hold amongst SME directors who are conscious of the many advantages of responsible management. The following section outlines practical examples of CSR with positive consequences for SMEs.

\section{Positive Examples and Consequences of CSR in SMEs}

According to several studies, implementation of CSR brings a certain number of advantages for a company- for instance enhanced reputation and corporate image, improvement of working relations with staff, improvement in production processes and quality (Vives, 2006; Saulquin \& Schier, 2007; Berger-Douce, 2008; Worthington et al., 2008; Russo \& Tencati, 2009).

According to Jenkins (2009), by adopting a CSR strategy, a SME can develop innovative products and services and thus take advantage of new and emerging markets. Several academic studies highlight the fact that responsible behavior brings financial advantages such as a reduction of costs and increased efficiency (Jenkins, 2009; Russo \& Tencati, 2009). In effect, by implementing more careful management practices and measures or using substitute 
products which are less harmful to the planet, a SME can reduce wastage and secure a reduction in costs or outlay (Reynaud \& Mathieu, 2005).

CSR can be a catalyst for increased motivation and productivity amongst a company's workforce (Saulquin \& Schier, 2007; Berger-Douce, 2008). At the same time, awareness and understanding of the challenges and issues involved in CSR can actually form a very good basis for competitive differentiation and ultimately contribute towards the improvement of company image. CSR can be viewed as a method of achieving company objectives and this can have a very helpful knock-on effect in communications with stakeholders - particularly company clients and commercial partners - the upshot of which will be enhanced corporate image and reputation (Collins et al., 2007).

Not all research studies agree with the latter however. Other academics believe that SMEs have a tendency to commit themselves to social responsibility for its own sake and do not seek to use it as a method of advertising themselves or as part of a PR exercise as is often the case in large companies (Jenkins, 2006). In fact, the rather informal strategy which characterizes the make up of an SME means that CSR tends to be more intuitive than strategic (Fassin, 2008) and that within a communications framework managing directors only use the strategic documents in their possession very rarely indeed.

As we have just demonstrated, a SME adopts responsible strategy for a variety of reasons.

\section{Conclusion and Discussion}

This study has enabled us to summarize the up-to-date position in relation to academic research on CSR in SMEs. The table below presents a summary of the main ideas discussed above. This is followed by a research proposal for specialists in the field.

Table 1. Research in the field of CSR in SMEs

\begin{tabular}{ll}
\hline $\begin{array}{l}\text { Definition of CSR in SMEs } \\
\text { and practices }\end{array}$ & $\begin{array}{l}\text { CSR in SMEs is on the increase. SME directors consider CSR not as an add-on but rather as part of their } \\
\text { overall day-to-day management. Their responsible practices can be classified into three main categories } \\
\text { namely internal social dynamics, external social dynamics and environmental dynamics. }\end{array}$ \\
\hline $\begin{array}{l}\text { Determining factors for } \\
\text { commitment to responsible } \\
\text { practice in SMEs }\end{array}$ & $\begin{array}{l}\text { Academic research reveals several factors which predispose towards commitment to CSR in a SME. The } \\
\text { central role played by the director himself or herself, internal and external proximity of the company and } \\
\text { finally small size of operation all tend to encourage development of ethical rather than economic } \\
\text { considerations. }\end{array}$ \\
\hline $\begin{array}{l}\text { Obstacles to adoption and } \\
\text { implementation of CSR in }\end{array}$ & $\begin{array}{l}\text { SMEs have certain weak spots such as the lack of resources, time and knowledge particularly of matters } \\
\text { pMEs }\end{array}$ \\
$\begin{array}{l}\text { pertaining to sustainable development. In commitments to CSR a SME faces obstacles linked to the market } \\
\text { particularly the difficulty of applying environmental and/or social regulations. Tools available are also poorly } \\
\text { adapted to SMEs. }\end{array}$ \\
$\begin{array}{l}\text { Ponsequences of CSR in } \\
\text { SMEs }\end{array}$ & $\begin{array}{l}\text { There are many advantages for a SME as a result of implementing a CSR strategy. For instance reduced costs } \\
\text { and increased efficiency bring financial advantage. In effect, by implementing more careful and cost saving } \\
\text { measures or introducing products less harmful to the environment, a SME can reduce waste and develop } \\
\text { innovative products and services. CSR also enables a business to increase the motivation and productivity of } \\
\text { its workforce. Being aware of the challenges of CSR can actually constitute the basis of competitive advantage } \\
\text { for the business and enhance corporate image. }\end{array}$ \\
\hline
\end{tabular}

As a result of studying these different research documents, a further area of study is now suggested- dealing with three different issues as follows:

Firstly, the existing studies do not discuss the dynamic dimension of CSR for a SME. So, following this up would be useful to understand the evolution of CSR practices better and to identify the stages of development towards CSR by way of longtitudinal case studies.

Next, by studying the determining characteristics of responsibility within SMEs, we have noticed that few research studies highlight particular business sector activities. It would be interesting to carry out comparative studies between different sectors in order to measure this influence.

Thirdly, in relation to challenges faced by SMEs in the implementation of responsible strategy, many studies confirm that the lack of resources represents a considerable obstacle. Examining the links between financial viability and commitment to responsible management for SMEs would therefore appear to be a promising avenue of further research. In our opinion, a comparative study would be most appropriate in order to examine whether viable SMEs can be distinguished from those with more limited resources. 
Finally, our literature review shows the need to develop tools for managing directors of SMEs. In order to do this it would be necessary to evaluate the effects of initiatives and campaigns to increase awareness by various public organizations more effectively than is currently the case.

\section{References}

ACFCI. (2006). La prise en compte du développement durable et de la responsabilité sociétale de l'entreprise (DD/RSE) par les PME/PMI, Octobre.

Berger-Douce, S. (2007). Freins et moteurs de l'engagement des PME dans une démarche de management environnemental. Lettre du management responsable, 7. http://www.esdes-recherche.net/.

Berger-Douce, S. (2008). Rentabilité et pratiques de RSE en milieu de PME: Premiers résultats d'une étude française. Revue Management et Avenir, 15, 9-29. http://dx.doi.org/10.3917/mav.015.0009

Berger-Douce, S. (2010). Gestion environnementale et certification: le cas de trois PME. Gestion, 35, 10-17. http://dx.doi.org/10.3917/riges.351.0010

Blombäck, A., \& Wigren, C. (2009). Challenging the importance of size as determinant for CSR activities. Management of Environmental Quality: An International Journal, 20(3), 255-270. http://dx.doi.org/10.1108/14777830910950658

Bowen, H. R. (1953). Social Responsibilities of the Businessman (p. 150). Ed. Harper and Brothers, New York.

Cabagnols, A., \& Le Bas, C. (2006). Les déterminants du comportement de responsabilité sociale de l'entreprise. Une analyse économétrique à partir de nouvelles données d'enquête. Premier Congrès du RIODD, Créteil, France, 7-8 décembre.

Collins, E., Lawrence, S., Pavlovich, K., \& Ryan, C. (2007). Business networks and the uptake of sustainability practices: the case of New Zealand. Journal of Cleaner Production, 15(8-9), 729-740. http://dx.doi.org/10.1016/j.jclepro.2006.06.020

Courrent, J-M. (2004). Ethique et petite entreprise. Revue Française de Gestion, 29(144), 139-152.

CROCIS-CCIP. (2007). Le développement durable dans les PME-PMI de la région parisienne. Baromètre 2007. http://www.crocis.ccip.fr

Ede, F. O., Panigraphi, B., Stuart, J., \& Calcich, S. (2000). Ethics in small minority business. Journal of Business Ethics, 26, 133-146. http://dx.doi.org/10.1023/A:1006309212031

Ellerup Nielsen, A., \& Thomsen, C. (2009). Investigating CSR communication in SMEs: a case study among Danish middle managers. Business Ethics: A European Review, 18(1), 83-94. http://dx.doi.org/10.1111/j.1467-8608.2009.01550.x

Fassin, Y. (2008). SMEs and the fallacy of formalising CSR. Business Ethics: A European Review, 17(4), 364-379. http://dx.doi.org/10.1111/j.1467-8608.2008.00540.x

Freeman, R. E. (1984). Strategic management: a stakeholder approach (p. 276). Pitman, Boston.

Gadenne, D. L., Kennedy, J., \& McKeiver, C. (2009). An Empirical Study of Environmental Awareness and Practices in SMEs. Journal of Business Ethics, 84(1), 45-64. http://dx.doi.org/10.1007/s10551-008-9672-9

Gond, J-P., \& Igalens, J. (2008). La responsabilité sociale de l'entreprise. PUF, Paris.

Hammann, E-M., Habisch, A., \& Pechlaner, H. (2009). Values that create value: socially responsible business practices in SMEs - empirical evidence from German companies. Business Ethics: A European Review, 18(1), 37-51. http://dx.doi.org/10.1111/j.1467-8608.2009.01547.x

Hemingway, C. A. (2005). Personal Values as A Catalyst for Corporate Social Entrepreneurship. Journal of Business Ethics, (60), 233-249. http://dx.doi.org/10.1007/s10551-005-0132-5

Jenkins, H. (2004). A critique of conventional CSR theory: an SME perspective. Journal of General Management, 9(4), 55-75.

Jenkins, H. (2006). Small Business Champions for Corporate Social Responsibility. Journal of Business Ethics, 67, 241-256. http://dx.doi.org/10.1007/s10551-006-9182-6

Jenkins, H. (2009). A ‘business opportunity’ model of corporate social responsibility for small- and medium-sized

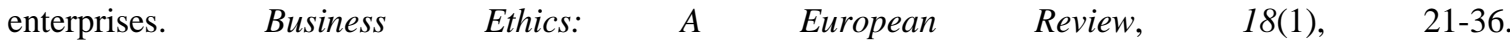
http://dx.doi.org/10.1111/j.1467-8608.2009.01546.x

Julien, P.-A., \& Marchesnay, M. (1996). L'entrepreneuriat (p. 112). Ed. Economica, Collection Gestion, Paris. 
Labelle, F., \& Saint Pierre, J., (2010). Lesdéterminants institutionnels,organisationnels et individuels dela sensibilité des PME au sujet du développement durable. 10ème Congrès International Francophone en Entrepreneuriat et PME, 27-29 Octobre, Bordeaux, France. 15p.

Lapointe, A., \& Gendron, C. (2004). Enseigner la RSE: des recettes utilitaristes à une réflexion critique sur l'entreprise comme institution sociale privée. 7ème Congrès de l'ADERSE, Toulouse, 21-22 octobre.

Lepoutre, J., \& Heene, A. (2006). Investigating the Impact of Firm Size on Small Business Social Responsibility: A Critical Review. Journal of Business Ethics, 67(3), 257-273. http://dx.doi.org/10.1007/s10551-006-9183-5

Mathieu, A., \& Reynaud, E. (2005). Lesbénéficesde laresponsabilité socialedel'entreprise pourles. PME:entre réductiondescoûtsetlégitimité. Revued'Economie Méditerranéenne, Octobre, 22p.

Murillo, D., \& Lozano, J. M. (2009). Pushing forward SME CSR through a network: an account from the Catalan $\begin{array}{lllll}\text { model. Business } & \text { Ethics: A }\end{array}$ http://dx.doi.org/10.1111/j.1467-8608.2009.01545.x

Observatoire des PME. (2003). Les PME et l'environnement. Enjeux et opportunités. Regards sur les PME, $n^{\circ} 4$, Agence des PME.

Paradas, A. (2006). Perception du développement durable par les dirigeants de petites entreprises: résultats d'enquêtes. 8ème Congrès CIFEPME, Fribourg, Suisse, 25-27 octobre.

Perrini, F., Russo, A., \& Tencati, A. (2007). CSR Strategies of SMEs and Large Firms. Evidence from Italy. Journal of Business Ethics, 74(3), 285-300. http://dx.doi.org/10.1007/s10551-006-9235-x

Quairel, F., \& Auberger, M.-N. (2007). La diffusion de la RSE par la relation fournisseurs. Injonctions paradoxales ou partenariat de progress?. RIPME, 20(3-4), 69-94.

Revell, A., \& Blackburn, R. (2007). The business case for sustainability? An examination of small firms in the UK's construction and restaurant sectors. Business Strategy and the Environment, 16(6), 404-420. http://dx.doi.org/10.1002/bse.499

Roberts, S., Lawson, R., \& Nicholls, J. (2006). Generating Regional-Scale Improvements in SME Corporate Responsibility Performance: Lessons from Responsibility Northwest. Journal of Business Ethics, 67(3), 275-286. http://dx.doi.org/10.1007/s10551-006-9184-4

Russo, A., \& Tencati, A. (2009). Formal vs. Informal CSR Strategies: Evidence from Italian Micro, Small, Medium-sized, and Large Firms. Journal of Business Ethics, 85(2), 339-353. http://dx.doi.org/10.1007/s10551-008-9736-x

Saulquin, J.-Y., \& Schier, G. (2005). Typologie des pratiques de RSE. Colloque GREFIGE-CEREMO, Agadir, avril.

Saulquin, J.-Y., \& Schier, G. (2010). Performance organisationnelle et responsabilité sociale de l'entreprise. In Dion, M. \& Wolff, D. (EdS.), Le développement durable, théories et applications au management, Ed. Dunod, 2ème Ed., pp. 127-142.

Saulquin, J-Y., \& Schier, G. (2007). Des perceptions managériales aux pratiques RSE: une étude exploratoire. Gestion 2000, 24(6), 181-195.

Sharma, S. (2000). Managerial Interpretations and Organizational Context as Predictors of Corporate Choice of Environmental Strategy. Academy of Management journal, 43(4), 681-697. http://dx.doi.org/10.2307/1556361

Spence, L. J. (1999). Does size matter? The state of the art in small business ethics. Business Ethics: A European Review, 8(3), 163-174. http://dx.doi.org/10.1111/1467-8608.00144

Spence, L. J., \& Lozano, J. F. (2000). Communicating about ethics with small firms: experiences from the UK and Spain. Journal of Business Ethics, 27, 43-53. http://dx.doi.org/10.1023/A:1006417425446

Spence, L. J., Habisch, A., \& Schmidpeter, R. (2004). Responsibility and Social Capital: The World of Small and Medium Sized Enterprises. Basingstoke: Palgrave Macmillan.

Spence, L. J., Schmidpeter, R., \& Habisch, A. (2003). Assessing social capital: small and medium sized enterprises in the UK and Germany. Journal of Business Ethics, 47(1), 17-29. http://dx.doi.org/10.1023/A:1026284727037 
Spence, L-J. (2007). CSR and Small Business in a European Policy Context: The Five Cs of CSR and Small Business Research Agenda 2007. Business and Society Review, 112(4), 533-552. http://dx.doi.org/10.1111/j.1467-8594.2007.00308.x

Spence, M., Ben BoubakerGherib, J., \& OndouaBiwolé, V. (2007a). Développement durable et PME: Une étude exploratoire des déterminants de leur engagement. Revue internationale des PME, 20(3/4), 17-42.

Spence, M., OndouaBiwolé, V., \& Ben Boubaker Gherib, J. (2007b). Une étude exploratoire du degré d'engagement des PME dans le développement durable. Actes des 10ème Journées Scientifiques du réseau entrepreneuriat de l'AUF, Antananarivo, 23-26 mai.

Studer, S., Welford, R., \& Hills, P. (2006). Engaging Hong Kong Business in environmental change: drivers and barriers. Business Strategy and the Environment, 15, 416-431. http://dx.doi.org/10.1002/bse.516

Torrès, O. (1999). LesPME. Ed. Flammarion, Paris, 128p.

Torrès, O. (2000). Du rôle et de l'importance de la proximité dans la spécificité de gestion des PME. $5^{\text {ème }}$ Congrès International Francophone PME, (CIFPME), Lille, octobre.

Torrès, O. (2003). Petitesse des entreprises et grossissement des effets de proximité. Revue Française de Gestion, (144), 119-138.

Vives, A. (2006). Social and Environmental Responsibility in Small and Medium Enterprises in Latin America. The Journal of Corporate Citizenship, 21, 39-50.

Watson, M., \& Emery, R. T. (2004). Environmental management and auditing systems: the reality of environmental self-regulation. Managerial Auditing Journal, 19(7), 916-928. http://dx.doi.org/10.1108/02686900410549439

Worthington, I., Ram, M., \& Jones, T. (2006). Exploring Corporate Social Responsibility in the U.K. Asian Small Business Community. Journal of Business Ethics, 67(2), 201-219. http://dx.doi.org/10.1007/s10551-006-9024-6

Worthington, I., Ram, M., Boyal, H., \& Shah, M. (2008). Researching the Drivers of Socially Responsible Purchasing: A Cross-National Study of Supplier Diversity Initiatives. Journal of BusinessEthics, 79(3), 319-331. http://dx.doi.org/10.1007/s10551-007-9400-x 